\title{
Kinerja Mengajar Dosen pada Masa Work From Home
}

\author{
Lulu Choirun Nisa ${ }^{1}$, Alfin Hikmaturrokhman ${ }^{2}$, Sunardi $^{3}$ \\ ${ }^{1}$ UIN Walisongo Semarang, ${ }^{2}$ Institut Teknologi Telkom Purwokerto, ${ }^{3}$ Universitas \\ Lambung Mangkurat
}

*Correspondence address: lulu.choirunnisa@walisongo.ac.id

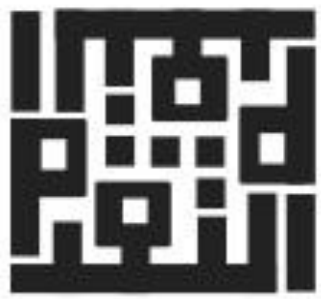

ISSN: 1979-4703 (p)

ISSN: 2527-9726 (e)

Keywords:

Online Learning,

Teaching Performance, Work From Home

\begin{abstract}
A B S T RAC'T
The Covid-19 pandemic has caused universities to adapt to various changes, especially lecture activities. The purpose of this article is to describe how lecturers carry out the teaching and learning process during a pandemic. The indicators are teaching methods, technology, schedules, evaluation techniques, and constraints. The data collection technique used a survey approach with 216 respondents. The analysis and discussion results show that the teaching method uses online discussions, online assignments, and virtual face-to-face meetings. In terms of technology, the majority of lecturers use the WA Group application, and the rest uses other media. For learning schedule indicators, the majority of lecturers deliver online learning according to the schedule. In evaluation techniques, most lecturers use online tests or quizzes to assess student achievement. The implementation of distance learning has obstacles, namely the achievement and competence of skills and technical barriers, such as signals, devices, and practical delivery skills.
\end{abstract}

\begin{abstract}
A B S T R A K
Pandemi Covid-19 menyebabkan perguruan tinggi dituntut untuk melakukan adaptasi terhadap berbagai perubahan, terutama aktivitas perkuliahan. Tujuan artikel ini untuk mendeskripsikan bagaimana dosen melaksanakan proses belajar mengajar saat bekerja dari rumah. Indikatornya adalah metode pengajaran, teknologi yang digunakan, jadwal, teknik evaluasi, dan kendala dosen. Studi ini menggunakan pendekatan survei dengan 216 responden. Hasil analisis dan pembahasan menunjukkan bahwa metode pengajaran menggunakan diskusi online, tugas online dan pertemuan tatap muka secara virtual. Dari segi teknologi, aplikasi WA Group digunakan mayoritas dosen, sisanya menggunakan media lain. Untuk indikator jadwal pembelajaran, mayoritas dosen menyampaikan pembelajaran secara online sesuai dengan jadwal. Pada teknik evaluasi, sebagian besar dosen menggunakan tes atau kuis online untuk menilai prestasi mahasiswa. Pelaksanaan pembelajaran jarak jauh terdapat kendala, yaitu pencapaian, dan kompetensi keterampilan, serta kendala teknis, seperti sinyal, perangkat, dan keterampilan penyampaian praktikum.
\end{abstract}




\section{Pendahuluan}

Tahun 2020 merupakan tahun yang akan dicatat dalam sejarah sebagai tahun dimana kehidupan sosial manusia berubah karena mewabahnya Corona Virus Disease (Covid19). Perubahan ini menjadi fenomenal karena tidak terjadi pada satu atau dua negara saja, namun terjadi secara global. Terhitung sampai tanggal 11 Mei 2020 atau hari ke-56 sejak kasus pertama tercatat, WHO melaporkan Covid-19 sudah ada di 213 negara dengan total kasus 4.006.257 kasus, 278.879 orang meninggal (Ainur Risalah et al., 2020; Amalia \& Fatonah, 2020; WHO, 2020; Wijoyo \& Indrawan, 2020). Sejak WHO meningkatkan status kejadian infeksi Covid-19 dari public health emergency of international menjadi pandemi pada tanggal 12 Maret 2020, penanganan terhadap penyebaran virus ini menjadi lebih masif. Pemerintah Indonesia sendiri telah menetapkan status keadaan darurat bencana wabah penyakit akibat virus corona mulai tanggal 28 Januari 2020 sampai 28 Februari 2020, yang kemudian diperpanjang sampai tanggal 29 Mei 2020 (Indrayana \& Sadikin, 2020).

Sebagai tindak lanjut status tersebut dan sebagai upaya pencegahan penyebaran Covid-19, Menteri PAN RB telah menetapkan penyesuaian kerja Aparatur Sipil Negara (ASN) dimana ASN dapat menajalankan tugas di rumah (Work From Home) sampai tanggal 31 Maret 2020, yang kemudian diperpanjang sampai 13 Mei 2020. Di lingkungan perguruan tinggi, upaya lebih teknis dikeluarkan oleh Menteri Pendidikan dan Kebudayaan secara gradual. Diawali dengan Surat Edaran Mendikbud Nomor 3 Tahun 2020 tanggal 9 Maret 2020 yang menghimbau beberapa protokol kesehatan di satuan kerja, Nomor 35492/2020 tanggal 12 Maret 2020 yang menunda penyelenggaraan kegiatan yang mengundang orang banyak, Nomor 36603/2020 yang membolehkan bekerja dari rumah, sampai Surat Edaran Nomor 36962 tanggal 17 Maret 2020 yang antara lain menyebutkan agar sivitas akademika bekerja dari rumah dan pembelajaran dilaksanakan dalam jaringan (daring). Untuk Perguruan Tinggi Keagamaan di lingkungan Kementerian Agama RI, instruksi serupa dikeluarkan oleh Dirjen Pendidikan Islam pada tanggal 26 Maret 2020 yang menyatakan bahwa proses akademik Semester Genap 2019/2020 sepenuhnya dilakukan secara daring.

Meski gaung pembelajaran daring sudah dihembuskan sejak munculnya isu Education 4.0, namun perubahan mode kerja dari tatap muka ke daring kali ini berlangsung teramat mendadak sehingga tidak seluruhnya dosen siap untuk melaksanakan kewajiban tridharma secara daring. Terlebih pada saat penetapan berlakunya WFH tersebut, kegiatan akademik sedang berada pada pertengahan Semester Genap tahun akademik 2019/2020. Sampai saat ini belum dapat dipastikan sampai kapan WFH akan diberlakukan. Oleh karena itu, perlu dilakukan evaluasi kinerja selama masa WFH secara berkesinambungan sehingga upaya perbaikan dan penjaminan mutu pembelajaran daring dapat dilakukan dengan terarah (Firman, 2020; Sadikin \& Hamidah, 2020).

Tujuan studi ini adalah untuk mendeskripsikan bagaimana dosen melakukan kinerja tridharma bidang pendidikan/pengajaran selama masa WFH diberlakukan. Melalui artikel ini dapat diidentifikasi perilaku dosen dalam menerapkan pembelajaran daring, sehingga 
dapat diidentifikasi hal-hal yang perlu dipenuhi dan ditingkatkan agar agar mutu pendidikan tetap terjaga meskipun pembelajaran dilakukan secara daring.

\section{Metode Penelitian}

Studi ini merupakan penelitian survei yang dilaksanakan pada minggu ke empat setelah diberlakukan WFH, yaitu tanggal 6-15 April 2020. Dengan demikian data dalam artikel ini mencerminkan proses adaptasi dosen di dalam melakukan pendidikan dan pengajaran pada masa WFH karena dilakukan pada bulan pertama WFH. Ruang lingkup studi ini adalah kinerja dosen dalam dharma pendidikan dan pengajaran mencakup pelaksanaan dan penilaian. Aspek perencanaan tidak termasuk yang diukur karena dosen sudah melaksanakan perencanaan pembelajaran di awal semester, dan WFH yang diberlakukan mendadak sebagai dampak dari kejadian darurat.

Pelaksanaan pengajaran dalam studi ini diukur melalui indikator metode pengajaran, media yang digunakan, waktu perkuliahan, evaluasi serta kendala yang duhadapi. Sedangkan aspek penilaian diukur melalui indikator metode dan kompetensi yang dinilai. Selain itu, artikel ini juga mencoba mengungkap kendala yang dialami dosen dalam melakukan pembelajaran daring. Instrumen yang digunakan adalah angket yang didistribusikan secara online melalui Google Form. Angket telah diuji validitas dan reliabilitas sehingga instrumen tersebut sudah layak digunakan. Responden adalah dosen di Indonesia, berjumlah sebanyak 220 orang, namun berdasarkan analisis konsistensi hasil isian, data yang valid dan layak olah berasal dari 216 responden. Responden berasal dari beberapa jenis PT, yaitu:

Tabel 1. Jumlah Responden

\begin{tabular}{l|c|c}
\hline \multicolumn{1}{c|}{ Jenis PT } & Jumlah Responden & $\mathbf{\%}$ \\
\hline PTN BLU & 82 & $38 \%$ \\
\hline PTN Satker & 73 & $34 \%$ \\
\hline PT Swasta & 50 & $23 \%$ \\
\hline PTN-BH & 11 & $5 \%$ \\
\hline Jumlah & $\mathbf{2 1 6}$ & \\
\hline
\end{tabular}

Berdasarkan jenis kelaminnya, 55\% (20 orang) adalah responden laki-laki dan 44\% (96 orang) adalah responden perempuan. Analisis data dilakukan dengan Statistika Deskriptif. 


\section{Hasil dan Pembahasan}

\section{Metode pengajaran}

Selama WFH karena proses pembelajaran dilakukan dengan terpisahkan oleh jarak, maka dapat dikatakan bahwa pembelajaran yang dilakukan adalah pembelajaran jarak jauh (Kaplan \& Haenlein, 2016). Metode pembelajaran jarak jauh ini menurut Kaplan dikategorikan ke dalam syncronous dan asyncronous. Metode syncronous merupakan metode dimana pendidik dan pembelajar hanya terpisah jarak namun melakukan proses pembelajaran secara bersama-sama. Sedangkan metode asyncronous merupakan metode dimana pendidik dan pembelajar tidak hanya terpisah jarak, namun juga terpisah waktu (Kaplan \& Haenlein, 2016). Artinya, memungkinkan bagi setiap pembelajar dapat belajar dengan kecepatan mereka masing-masing dan memiliki kemajuan belajar yang berbeda dengan yang lain. Berdasarkan hasil pengambilan data, metode pengajaran jarak jauh yang dipilih oleh dosen terdiri dari penugasan, diskusi online, ceramah melalui tatap muka online dan metode lain yang tidak disebutkan secara rinci. Persentase dari banyaknya dosen yang menggunakan metode-metode tersebut dapat disajikan dalam gambar 1 berikut.

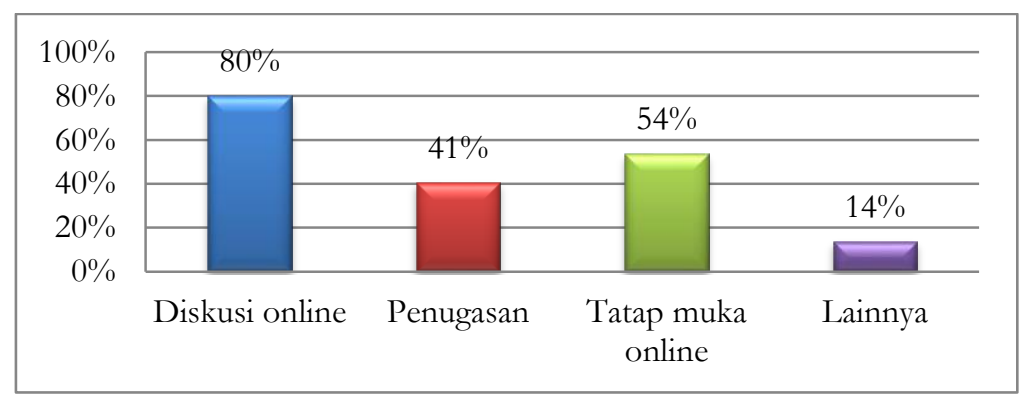

Gambar 1. Metode Pengajaran Jarak Jauh yang Digunakan

Sebagaimana terlihat pada Gambar 1 di atas, pada masa adaptasi WFH ini mayoritas dosen menggunakan metode diskusi online, dan lebih dari separo dosen menggunakan metode tatap muka online, serta sebagian (41\%) menggunakan metode penugasan. Beberapa dosen melakukan kombinasi dari beberapa metode yang berberda untuk menyampaikan materi. Rincian kombinasi tersebut adalah sebagai berikut.

Tabel 2. Kombinasi Metode Pengajaran

\begin{tabular}{lcc}
\hline \multicolumn{1}{c}{ Metode } & $\boldsymbol{f}$ & $\mathbf{\%}$ \\
\hline Diskusi online & 49 & $22,7 \%$ \\
\hline Penugasan, Tatap Muka online, Diskusi online & 48 & $22,2 \%$ \\
\hline Penugasan, Diskusi online & 28 & $13,0 \%$ \\
\hline Tatap Muka online, Diskusi online & 24 & $11,1 \%$ \\
\hline Tatap Muka online & 21 & $9,7 \%$ \\
\hline
\end{tabular}




\begin{tabular}{lcc}
\hline \multicolumn{1}{c}{ Metode } & $\boldsymbol{f}$ & $\mathbf{\%}$ \\
\hline $\begin{array}{l}\text { Penugasan, Tatap Muka online, Diskusi online, } \\
\text { Lainnya }\end{array}$ & 13 & $6,0 \%$ \\
\hline Penugasan, Diskusi online, Lainnya & 9 & $4,2 \%$ \\
\hline Penugasan, Tatap Muka online & 9 & $4,2 \%$ \\
\hline Penugasan & 7 & $3,2 \%$ \\
\hline Lainnya & 4 & $1,9 \%$ \\
\hline Diskusi online, Lainnya & 2 & $0,9 \%$ \\
\hline Penugasan, Lainnya & 1 & $0,5 \%$ \\
\hline Penugasan, Tatap Muka online, Lainnya & 1 & $0,5 \%$ \\
\hline Jumlah & $\mathbf{2 1 6}$ & $\mathbf{1 0 0 , 0} \%$ \\
\hline
\end{tabular}

Tabel 2 di atas menunjukkan bahwa mayoritas dosen menggunakan kombinasi metode pengajaran yang berbeda. Hal ini mengindikasikan upaya yang cukup baik dari para dosen untuk memastikan mahasiswa melakkukan pembelajaran yang memadai. Selain itu, kombinasi metode yang dilakukan juga memperbesar peluang keberhasilan pembelajaran, sebagaimana yang disampaikan oleh Piskurich bahwa dari sekian banyak kategori metode instrusional, proses training atau pembelajaran yang paling banyak suksesnya adalah yang mengkombinasikan beberapa metode (Parker, 2012). Tabel di atas juga menunjukkan bahwa cukup banyak dosen yang mengkombinasikan antara metode asyncronous melalui penugasan dengan metode syncronous melalui tatap muka secara online.

\section{Teknologi}

Pandemi Covid-19 dan keputusan pemberlakuan WFH yang mendadak tidak memberikan waktu yang cukup banyak bagi dosen untuk mendesain media atau teknologi yang dapat digunakan untuk pengajaran jarak jauh. Teknologi yang dimaksud dalam studi ini adalah kumpulan alat yang digunakan oleh dosen untuk menyampaikan materi pembelajaran dan untuk memfasilitasi komunikasi antar peserta (Fariyani et al., 2020; Negash et al., 2008).. Berdasarkan hasil pengambilan data, beberapa teknologi yang digunakan pada bulan pertama WFH adalah sebagaimana yang tersaji pada Gambar 2 berikut. 


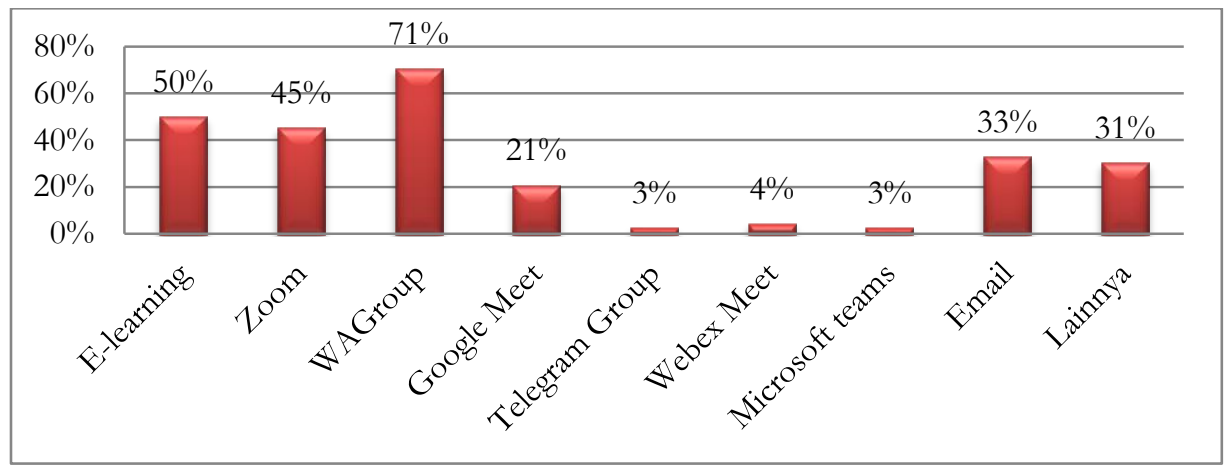

Gambar 2. Teknologi yang Digunakan

Melihat variansi dari teknologi yang digunakan oleh dosen, mayoritas dosen menggunakan model pengajaran berbasis online, kecuali 31\% dosen yang menyebutkan menggunakan media lain yang tidak disebutkan. Media lain tersebut bisa saja menggunakan teknologi yang berbasis cetak (correspondence moded) atau berbasis multimedia (radio, televisi, dsb). Dari berbagai teknologi yang disebutkan oleh responden, terlihat bahwa ada tiga kelompok teknologi yang digunakan, yaitu:

a. Teknologi berbasis Learning Management System (e-learning);

b. Teknologi tatap muka virtual atau teleconference (seperti zoom, Google Meet, Webex meet, Microsoft Teams); dan

c. Teknologi komunikasi text berbasis mobile (seperti WhatsApp Group, telegram Group, dan email).

Data juga menunjukkan bahwa beberapa dosen menggunakan kombinasi teknologi yang berbeda, sebagaimana ditunjukkan pada Tabel 3 berikut.

Tabel 3. Kombinasi Metode Pengajaran

\begin{tabular}{lcc}
\hline \multicolumn{1}{c}{ Jenis Media } & Jumlah & Persen \\
\hline LMS & 16 & $7 \%$ \\
\hline Virtual Meeting & 20 & $9 \%$ \\
\hline Text & 35 & $16 \%$ \\
\hline LMS, Virtual Meeting & 16 & $7 \%$ \\
\hline LMS, Text & 33 & $15 \%$ \\
\hline Virtual Meeting, Text & 39 & $18 \%$ \\
\hline LMS, Virtual Meeting, Text & 49 & $23 \%$ \\
\hline Lainnya & 8 & $4 \%$ \\
\hline Jumlah & $\mathbf{2 1 6}$ & $\mathbf{1 0 0 \%}$ \\
\hline
\end{tabular}

Dari Tabel 3 di atas terlihat bahwa mayoritas dosen yaitu sebesar 23\% menggunakan kombinasi antara LMS, virtual meeting, dan text sebagai media pembelajaran mereka. Meskipun grafik pada gambar 3 menunjukkan bahwa WA Group adalah media yang 
paling dominan digunakan, namun Tabel 3 mengindikasikan bahwa mayoritas dosen menganggap pengajaran melalui diskusi text online saja tidak cukup.

Tabel 3 juga menyajikan data bahwa terdapat 57\% dosen menggunakan media virtual meeting, baik itu Zoom, Google Meet, Webex Meet, maupun Microsoft Teams. Ini menunjukkan bahwa meskipun pembelajaran jarak jauh, interaksi face to face antara dosen dan mahasiswa cukup tinggi. Komunikasi real-time jenis ini sangat berharga sebagai pengganti tatap muka karena ada manfaat secara emosional dan intelektual dari berbicara secara real time kepada dosen maupun teman sebaya (Burns, 2011). Melalui komunikasi virtual ini pendidik atau dosen juga bisa mendengar dan mengobservasi gesture dan nada bicara mahasiswa.

\section{Waktu Pengajaran}

Pembelajaran jarak jauh memungkinkan bagi pendidik untuk melakukan pengajaran kapanpun. Namun karena mahasiswa juga dibebani oleh beberapa mata kuliah, maka studi ini akan melihat apakah dosen melakukan perubahan waktu pengajaran atau tetap menggunakan jadwal yang sama dengan pengajaran sebelum WFH.

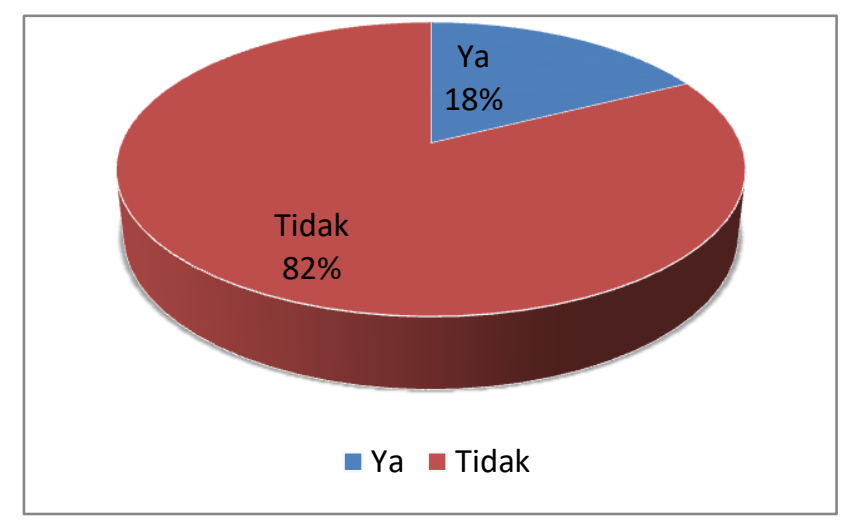

Gambar 3. Jadwal Pengajaran selama WFH

Dalam hal waktu pelaksanaan pembelajaran, $82 \%$ menyatakan pembelajaran daring yang dilakukan tetap sesuai jadwal perkuliahan. Sementara sisanya, yaitu sebesar 18\% melaksanakan pengajaran dengan jadwal yang berbeda.

\section{Metode Evaluasi}

Permendikbud Nomor 3 Tahun 2020 tentang Standar Nasional Pendidikan Tinggi menyebutkan bahwa Evaluasi merupakan salah satu kegiatan pokok dosen yang termasuk beban kerja dosen. Beberapa teknik penilaian yang disebutkan di dalam Permendikbud tersebut antara lain adalah observasi, partisipasi, performance, tes tertulis, tes lisan dan angket. Namun tidak semua teknik evaluasi tersebut dapat dilaksanakan dalam pembelajaran jarak jauh. Berdasarkan hasil pengolahan data, beberapa teknik evaluasi yang digunakan selama WFH ini adalah proyek, kuis/angket, tes oline, 


\section{At-Taqaddum}

Vol. 12 No. 2 (2020) 103-112

portofolio, dan teknik lainnya yang tidak disebutkan. Distribusi penggunaan teknikteknik tersebut disajikan dalam Gambar 4 di bawah ini.

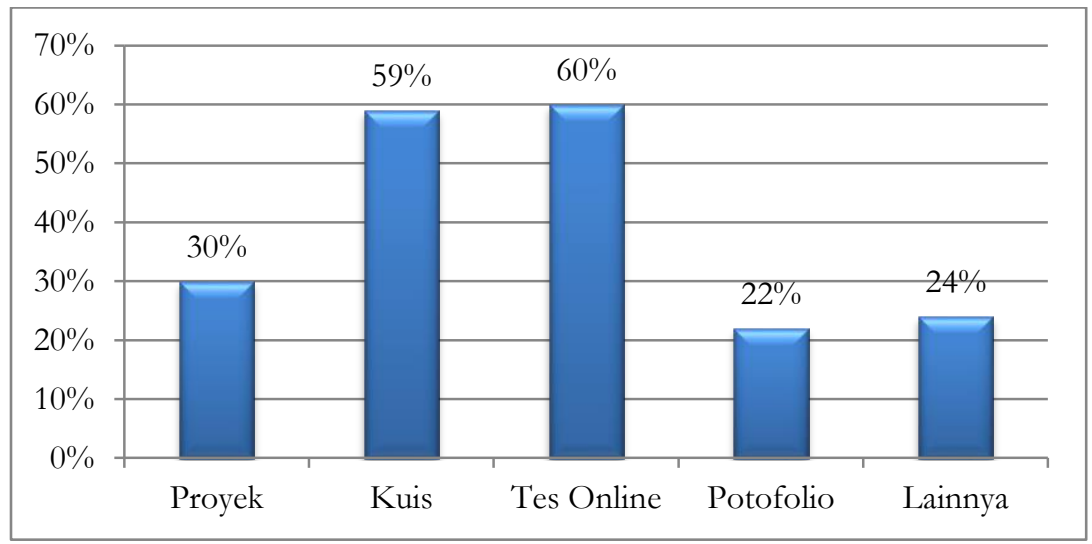

Gambar 4. Teknik Evaluasi Pembelajaran selama WFH

Grafik di atas menunjukkan bahwa metode tes dan kuis merupakan teknik evaluasi terbanyak yang dilakukan oleh dosen. Teknik evaluasi ini merupakan teknik yang juga lazim dilakukan pada pembelajaran luring. Hanya saja selama WFH ini tes atau kuis tersebut dilakukan secara online. Teknik penilain lainnya yang juga cukup banyak digunakan oleh dosen adalah dengan proyek dan portofolio. Proyek merupakan teknik evaluasi berupa penugasan atau permasalahan yang harus dipecahkan, sedangkan portofolio merupakan teknik evaluasi dengan mengumpulkan dan melihat progres mahasiswa dari beberapa karya.

\section{Kendala}

Ada dua jenis kendala yang dihadapi oleh dosen, yaitu kendala untuk memenuhi kompetensi mahasiswa dan kendala teknis. Meskipun demikian, tidak semua dosen menyatakan memiliki kendala. Dalam hal ketercapaian kompetensi mahasiswa, 17\% dosen menyatakan kompetensi yang diharapkan dari mahasiswa dapat tercapai meskipun melalui pembelajaran jarak jauh. Namun sisanya, menyatakan terkendala untuk mengukur dan mengetahui beberapa kompetensi, khususnya pada:

a. Kompetensi Sikap dan soft skills, seperti keaktifan, kemampuan kerjasama, komunikasi, dan kejujuran

b. Kompetensi Keterampilan, seperti keterampilan berhitung dan keterampilan berbahasa, aksiologi

c. Kompetensi keterampilan khusus yang membutuhkan praktikum di laboratorium

d. Kompetensi pengetahuan pada ranah berpikir tingkat tinggi

Dalam hal teknis, kendala kuota internet sangat mendominasi, dimana $62 \%$ dosen manyatakan hal ini. Hal ini dapat dipahami karena konferensi video menuntut transmisi dua arah video full-motion dan audio berkualitas tinggi yang sangat tinggi. Kendala 
lainnya adalah tidak semua mahasiswa memiliki perangkat dan sinyal yang memadai untuk dapat mengikuti pembelajaran online. Hal ini disampaikan oleh $25 \%$ responden atau 55 orang dosen. Berikut adalah daftar kendala teknis yang terdata.

Tabel 4. Kendala Teknis Pembelajaran Jarak Jauh

\begin{tabular}{ccc}
\hline Kendala & $\boldsymbol{f}$ & $\mathbf{\%}$ \\
\hline Kuota internet & 133 & $62 \%$ \\
\hline Media/Alat IT & 60 & $28 \%$ \\
\hline Sinyal & 55 & $25 \%$ \\
\hline Praktikum & 98 & $45 \%$ \\
\hline Lainnya & 47 & $22 \%$ \\
\hline
\end{tabular}

\section{Kesimpulan}

Deskripsi data di atas menunjukkan bahwa dosen sudah melaksanakan pembelajaran jarak jauh dengan metode yang bervariasi, bahkan dengan kombinasi beberapa metode. Hal ini menunjukkan adanya upaya dari dosen untuk tetap melaksanakan pembelajaran sebagaimana seharusnya. Diskusi online menjadi metode paling banyak digunakan, dan selaras dengan itu WhatsApp Group menjadi teknologi paling banyak digunakan. Secara umum ada tiga jenis teknologi yang digunakan sebagai sarana pembelajaran, yaitu teknologi berbasis LMS, teleconference dan teknologi berbasi komunikasi text online. Perilaku penggunaan teknologi tersebut menunjukkan bahwa mayoritas dosen menggunakan multiteknologi atau kombinasi teknologi yang berbeda untuk mencapai tujuan pembelajarannya. Untuk evaluasi pembelajaran, data menunjukkan adanya teknik evaluasi yang cukup beragam yang dilakukan oleh dosen, yaitu kuis/angket, tes online, portofolio, penilaian proyek dan teknik lain yang tidak disebutkan. Dalam hal evaluasi pelaksanaan pembelajaran online itu sendiri, dosen mengalami kendala dalam memenuhi kompetensi yang harus dikuasai mahasiswa dan kendala secara teknis. Dalam hal kendala ketercapaian kompetensi, responden menyampaikan bahwa di dalam pembelajaran jarak jauh atau pembelajaran online, dosen kesulitan untuk mengetahui ketercapaian kompetensi pengetahuan pada level berpikir tingkat tinggi, kompetensi sikap dan keterampilan, terutama keterampilan yang membutuhkan praktikum di laboratorium atau di lapangan. Secara teknis, kendala yang dialami dosen adalah dalam hal ketersediaan kuota khususnya bagi mahasiswa, ketersediaan infrastruktur IT, dan sinyal.

\section{Daftar Pustaka}

Ainur Risalah, W Ibad, L Maghfiroh, M I Azza, S A Cahyani, \& Z A Ulfayati. (2020). Dampak Pandemi Covid-19 Terhadap Kegiatan Belajar Mengajar Di MI/SD (Studi KBM Berbasis Daring Bagi Guru dan Siswa). JIEES : Joumal of Islamic Education at 


\section{At-Taqaddum}

Vol. 12 No. 2 (2020) 103-112

Elementary School, 1(1), 10-16. https://doi.org/10.47400/jiees.v1i1.5

Amalia, A., \& Fatonah, S. (2020). Penerapan Pembelajaran Daring Dragonlearn pada Era Pandemic Covid-19 (Studi Kasus di MI Ma’had Islam Kopeng). ISEJ: Indonesian Science Education Journal, 1(3), 148-164. https://siducat.org/index.php/isej/article/view/81

Burns, M. (2011). Distance Education for Teacher Training: Modes, Models, and Methods. 338.

Fariyani, Q., Mubarok, F. K., Masfu'ah, S., \& Syukur, F. (2020). Pedagogical Content Knowledge of Pre-service Physics Teachers. Jurnal Ilmiah Pendidikan Fisika AlBiRuNi, 9(1), 99-107. https://doi.org/10.24042/jipfalbiruni.v9i1.3409

Firman. (2020). Dampak Covid-19 terhadap Pembelajaran di Perguruan Tinggi. Bioma, 2(1), 14-20.

Indrayana, B., \& Sadikin, A. (2020). Penerapan E-Learning Di Era Revolusi Industri 4.0 Untuk Menekan Penyebaran Covid-19. Indonesian Journal of Sport Science and Coaching, 2(1), 46-55. https://doi.org/10.22437/ijssc.v2i1.9847

Kaplan, A. M., \& Haenlein, M. (2016). Higher education and the digital revolution: About MOOCs, SPOCs, social media, and the Cookie Monster. Business Horizons, 59(4), 441-450. https://doi.org/10.1016/j.bushor.2016.03.008

Negash, S., Whitman, M. E., Woszczynski, A. B., Hoganson, K., \& Mattord, H. (2008). Handbook of distance learning for real-time and asynchronous information technology education. In Handbook of Distance Learning for Real-Time and Asynchronous Information Technology Education. IGI Global. https://doi.org/10.4018/978-1-59904964-9

Parker, J. (2012). Instructional Methods for Online Learners. In Pedagogical and Andragogical Teaching and Learning with Information Communication Technologies (pp. 122134). IGI Global.

Sadikin, A., \& Hamidah, A. (2020). Pembelajaran Daring di Tengah Wabah Covid-19. Biodik, 6(2), 109-119. https://doi.org/10.22437/bio.v6i2.9759

WHO. (2020). Coronavirus disease. In World Health Organization (Vol. 2020, Issue March). https://doi.org/10.1001/jama.2020.2633

Wijoyo, H., \& Indrawan, I. (2020). Model Pembelajaran Menyongsong New Era Normal Pada Lembaga Paud Di Riau. JS (Jurnal Sekolah) Universitas Negeri Medan, 4(3), 205212. https://doi.org/https://doi.org/10.24114/js.v4i3.18526 